\title{
Aircraft manufacturers marketing warfare
}

\author{
Benedikt Badánik ${ }^{1, *}$, and Karol Götz ${ }^{2}$ \\ ${ }^{1}$ University of Zilina, Air Transport Department, Univerzitná 1, 01001 Žilina, Slovakia \\ ${ }^{2}$ Winsland Consulting Ltd., England
}

\begin{abstract}
As modern aircraft manufacturing becomes increasingly competitive and complex, there is an ever-expanding need for effective marketing. Never before has it been more vital for aircraft manufacturers' sales departments to transmit sales messages that inform, persuade, entertain, motivate and inspire. The question is: "What makes the aircraft sales campaign successful and how aircraft manufacturer can succeed against competitors?" Are there any differences between "big" and "small" players on the market? This paper offers number of insights on how aircraft manufacturers do their daily aircraft sales and marketing process. It points out major differences in how it is exercised by large and small aircraft manufacturers. The paper also suggests that if aircraft manufacturer is to be successful today, it must become competitor-oriented rather than customer-oriented. It must look for weak points in the positions of its competitors and then launch marketing warfare against those weak points.
\end{abstract}

\section{Aircraft manufacturers' marketing}

\subsection{Product}

Many consider aircraft a major marketing product. However, this term includes many objects starting with seat comfort, going thru catering possibilities, flight performance, weights and whole list of other more or less important subjects, which define the right product for the right market with desired characteristics [1].

This product known as an aircraft is subject of studies for airline marketing. To find and compile the right product for customer there is a need to revise, optimize and harmonize customer's demand with actual passenger or customer demand and forecasted future evolution of air transport system [2].

Even if product outer characteristics looks to be nearly the same, for example the aircraft type is the same category, let's say Airbus A330 or Boeing B777, there could be a lot of differences inside the product itself, which are price making and distinguishing products for different customers and markets. It means aircraft manufacturers are given a hard time defining the right product for particular market or customer, because demand varies to a great extent and whole process of customizing needs to be started repeatedly for each case study [3].

\footnotetext{
* Corresponding author: benedikt.badanik@fpedas.uniza.sk
} 
Aircraft product characteristics can be divided into five main groups:

Table 1. Marketing view on aircraft product characteristics ${ }^{\dagger}$

\begin{tabular}{ll}
\hline Cabin characteristics & $\begin{array}{l}\text { Seating comfort - seat count, seat pitch, seat width, seat } \\
\text { availability to recline, cabin air humidity, cabin air } \\
\text { temperature, cabin air pressure, different types of ratios - } \\
\text { lavatory ration, trolley ration, shower ratio, stowage ration, } \\
\text { IFE - inflight entertainment system, social areas, duty free } \\
\text { shops, etc. }\end{array}$ \\
& $\begin{array}{l}\text { Maximum take-off weight/payload/range, performance on } \\
\text { high and hot airfields, take off distance needed, landing } \\
\text { distance needed, etc. }\end{array}$ \\
\hline $\begin{array}{l}\text { Performance } \\
\text { characteristics }\end{array}$ & $\begin{array}{l}\text { Maintenance costs, maintenance centers, maintenance } \\
\text { commonality, etc. }\end{array}$ \\
\hline Aircraft maintenance & Cockpit layout, fuel consumption, noise, etc. \\
\hline Technical characteristics & Capacity/possible yield, total costs and revenues, etc. \\
\hline characteristics &
\end{tabular}

\subsection{Price}

Price is one of the most powerful argument together with superiority of the product. Customers are about to negotiate the best price. On the other hand, a marketing team needs to provide manufacturer's negotiator with strong arguments presenting the product price as much reasonable as possible. Price should represent the quality of the product, technology level, its superiority, and finally yet importantly perceived benefit [4-7].

Benefit could be perceived in dozens different ways. Some airline customers consider aircraft technical superiority a real benefit. Airline, for example chooses Boeing B787 instead of Airbus A330 because of its high-tech features e.g. composite body, modern interior, lower cabin altitude - cabin air pressure, etc. [8]

Other benefit of an aircraft could be ability to take-off fully loaded from high and hot airport. For example, customer could choose an Airbus A350 instead of a Boeing B777, because of its better performance on high and hot airports without considering the price [9].

Aircraft manufacturers' pricing policies are not known to great extent. Manufacturers try to keep their pricing structures confidential. However, the following aspects can provide for a clear view of different aircraft pricing approaches.

Usually the price depends on:

- The quality of the product

- Technological level

- Superiority

- Materials used

- Human working hours

- Reasonable profit

\subsection{Promotion}

Aircraft manufacturers usually distinguish between "pre-rollout" promotion and "afterrollout" promotion $[10,11]$.

Pre-rollout promotion is focusing on promoting and selling the product, which is not available in physical form yet (non-existing aircraft). Negotiating and promoting features of

\footnotetext{
${ }^{\dagger}$ Based on personal consultations of Karol Götz with senior marketing analysts of Airbus
} 
non-existing aircraft is demanding but manufacturers have all the data and tools to be able to promote this kind of aircraft/product. It is truly harder to promote and negotiate without feedbacks from the real service. Data and feedbacks from real service are very important during building the marketing campaign arguments. There could be a risk of disappointment/satisfaction on customer side after entry into service based on many different reasons such as:

- Pilot negative/positive feedback

- Passenger negative/positive feedback

- Flight crew negative/positive feedback

Good but surprising example of negative feedback is airbus A380. "Extremely silent operations" of an aircraft was communicated before entry into service and it remains one of the main marketing arguments nowadays. The truth is that Airbus A380 is so silent that pilots and cabin crew from Emirates airlines are complaining about that. They cannot sleep well in a crew rest compartment because the noise caused by aircraft is lower than noise made by passengers.

After rollout promotion has the same role as pre-rollout promotion. It has to point out the main reasons why to purchase "our" aircraft and not "their" one. Comparison with competitors is taking place.

Aircraft manufacturer marketing is not only to promote an aircraft itself. Marketing process has also to promote other operational-related benefits of an aircraft; e.g. pre-sale pilot training, possibility to find the best way of leasing.

\subsection{Place}

Obvious question for airlines is whether to buy or lease an aircraft. There is increasing number of airlines deciding for operating leasing. More than one-quarter of the production of the two principal airframe manufacturers is destined for the leasing companies [12].

Aircraft availability is of huge concern in most cases. The ability of the manufacturer to deliver a purchased aircraft to an airline is partly a function of the amount of his production already committed to the leasing fraternity. The manufacturer has an interest in regulating how many aircraft are in the hands of the leasing companies. Too many, and the manufacturer may risk competing with the lessors to place aircraft. Too few, and opportunities to place aircraft may be less evident [12].

\section{Large aircraft manufacturers' peculiarities}

When does the marketing process start? This is a very important question. In fact, it does not look like the marketing process is involved so much in the sales process. However, the opposite is truth. The marketing department is supporting the sales process all the way practically from the beginning until the very end. Example of large aircraft manufacturers (e.g. Airbus, Boeing, etc.) shows that the marketing process is crucial part of the sales process. Neither it starts with the aircraft sales, nor does it terminate with aircraft delivery. Marketing process is continuous and exists even before the sales process starts and after the aircraft delivery is completed [13-16].

\subsection{Aircraft sales process}

Aircraft sales process is a long lasting procedure including different types of activities in several interrelated phases [17]. These phases are different for each manufacturer but the 
processes and activities are nearly the same for each campaign. Any campaign that is in progress is influenced by customer demand depending on several factors.

Factors driving customer demand could be as follows:

- Route conditions - route length, airport altitude, average temperature of the airport, RWY length, landscape around the airport (desert, city, mountains, etc.)

- Company business model - low cost carrier, full service carrier, VIP model carrier, mixed model carrier, leasing company, military services, rescue services of all kinds, etc.

- Passenger demand - rising demand in region, demand for comfort and related services, price sensitivity

- Population (demographic) changes - education, woman power, enlarging of population, purchasing power, propensity to fly, etc.

- Airline competitors' activity - introduction of new routes, change of comfort, precise differentiation of products, upgrading of product and services (things that can make difference: IFE, alcohol, cutlery, cuisine, lavatory, etc.)

- Aircraft manufacturer competitor activity - upgrading and improvement of existing product (lower consumption, increasing of payload, increasing of in-service hours) introducing of new products (revolutionary products - composite aircraft, safety improvement, etc.) introducing of new solutions or added values (cabin air quality, lower cabin air pressure, LED mood lighting, etc.)

- Aviation regulations changes - for example environmental regulations (emission rules, noise restrictions, etc.), state civil aviation authority regulations, airport regulations, air navigation services regulations changes

- Political changes - change of political organization (could be the reason of cancelation or changes in orders)

- Disasters and contingencies - economic crisis, natural disaster, bankruptcy, war

- Introduction of new product - seats, materials, navigation possibilities, performance improvements, etc. [18]

Aircraft sales process is supported by the cabin layout. It serves as a basis for performance and economic analysis. It is crucial in order to gain better competitive position. In the phase of providing marketing argumentation an evaluation layout is prepared, and in the phase of cabin definition, the definition layout is drawn [19-27]. 


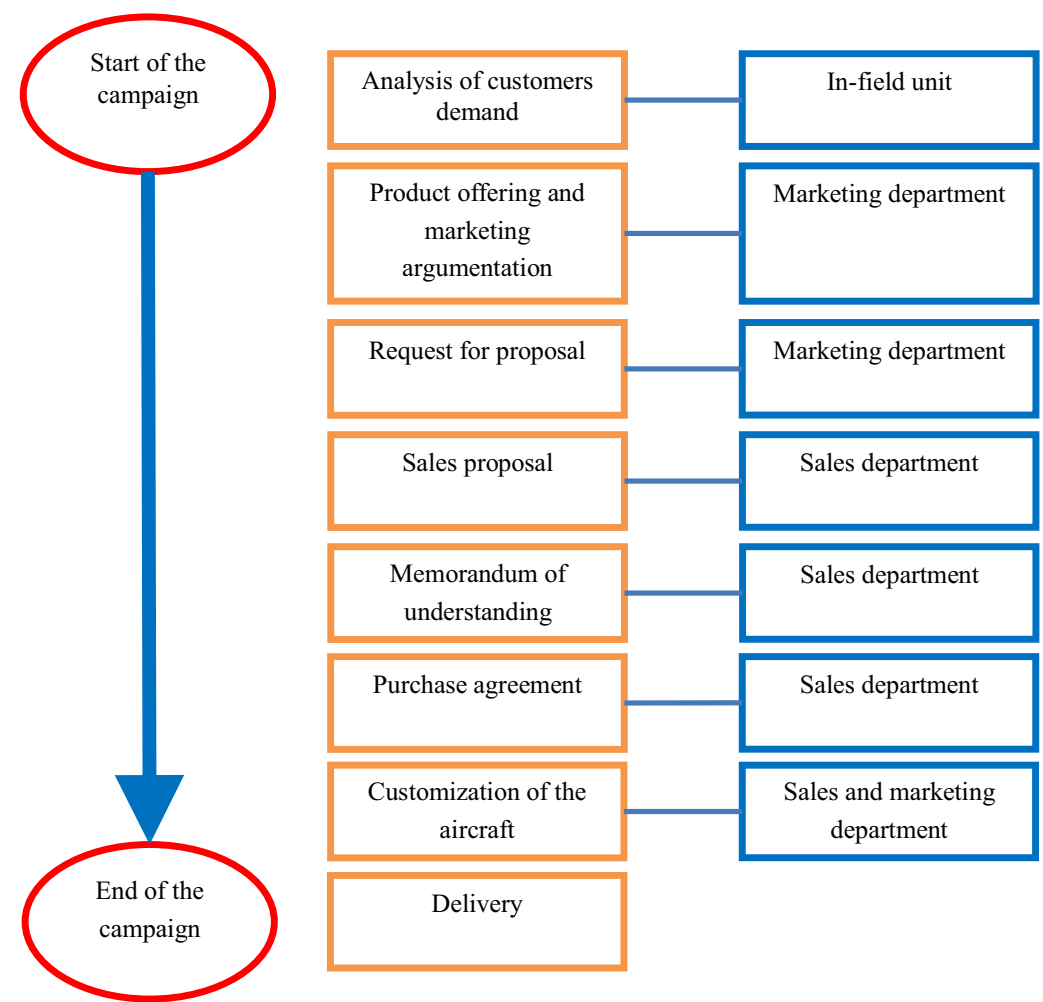

Fig. 1 Relationship of aircraft sales campaign with large aircraft manufacturer departments. Source: [11]

\section{Small aircraft manufacturers' peculiarities}

Small manufacturers are those, which are producing small amount of planes every year. For example Czech company called Aircraft Industries is producing airplanes with capacity up to 19 passengers. Their production capacity should reach 12 airplanes produced in year 2017. [28]

Small manufacturers' production is focused on small amount of small aircraft. They are usually producing propeller and small turbo-propeller planes.

There is couple of typical differences between small manufacturers and large manufacturers (as outlined in Chapter 4).

Typical small aircraft manufacturer characteristics:

- production usually includes just one or two airplanes models (Aircraft industries L410/L420, Aero spool - WT 9 Dynamic, etc.)

- factory office building is normally based on one place together with final assembly line (usually on some local airport)

- marketing department has two employees on average

- small manufacturers are outsourcing a lot of activities to independent sellers (distribution, communication with final customer, expo attendance, etc.) 
Four elements (four Ps - product, price, promotion, place) are the controllable marketing factors that should be used to reach the target market. Thus, any discussion of the business activities that direct the flow of services to customers must stress the four Ps. Because all four elements are present to some degree in any marketing situation, the manufacturer marketing team task is not to decide whether to use a particular element, but rather to determine the relative emphasis to place on each element in the final marketing program [29-30].

\section{Large vs. small - comparison of marketing processes}

Table 2 depicts differences between large and small aircraft manufacturer in terms size of market served, manufacturer's company size, marketing department size and production capacity. Table 3 depicts Comparison of large and small aircraft manufacturers' marketing departments and activities.

Table 2 General characteristics comparison of large and small aircraft manufacturer

\begin{tabular}{|c|c|}
\hline Large aircraft manufacturer & Small aircraft manufacturer \\
\hline \multicolumn{2}{|c|}{ Market served } \\
\hline $\begin{array}{c}\text { Large airlines all around the world with } \\
\text { different business models, governments, etc. }\end{array}$ & $\begin{array}{c}\text { Small private companies usually with local } \\
\text { importance, pilot schools, individuals, etc. }\end{array}$ \\
\hline \multicolumn{2}{|c|}{ Manufacturer's company size } \\
\hline Over than fifty thousand employees & Up to one hundred employees \\
\hline \multicolumn{2}{|c|}{ Marketing department size } \\
\hline Over one hundred employees & Average maximum of two employees \\
\hline \multicolumn{2}{|c|}{ Production capacity } \\
\hline Over than five hundred airplanes per year & Not more than hundred airplanes per year \\
\hline
\end{tabular}

Table 3 Comparison of large and small aircraft manufacturers' marketing departments and activities

\begin{tabular}{|c|c|}
\hline Large aircraft manufacturer & Small aircraft manufacturer \\
\hline \multicolumn{2}{|c|}{ Marketing department organizational structure } \\
\hline $\begin{array}{c}\text { Different offices - different subjects: } \\
\text { - aircraft interior marketing office } \\
\text { - aircraft performance marketing office } \\
\text { - aircraft technical marketing office } \\
\text { - future market development office } \\
\text { - infield marketing office }\end{array}$ & $\begin{array}{c}\text { One marketing department composed of one } \\
\text { marketing office usually dedicated to product data } \\
\text { gathering and product promotion (in terms of 4Ps) }\end{array}$ \\
\hline $\begin{array}{c}\text { Marketing managers have the power to sing } \\
\text { some of the documents related to the sales } \\
\text { process. }\end{array}$ & $\begin{array}{c}\text { Marketing employees have responsibilities to } \\
\text { gather and produce data related to the marketing } \\
\text { process and have no power to sing any document } \\
\text { related to the sales process.. }\end{array}$ \\
\hline $\begin{array}{c}\text { Marketing process supports the sales process } \\
\text { all the way from the beginning until the very } \\
\text { end of the sales process - delivery. }\end{array}$ & $\begin{array}{c}\text { Marketing process is focused mainly on } \\
\text { promotion. }\end{array}$ \\
& $\begin{array}{c}\text { Price is set by sales department. } \\
\text { the company }\end{array}$ \\
\hline $\begin{array}{c}\text { Marketing process create and provides all the } \\
\text { data, information and marketing } \\
\text { argumentations needed such as: }\end{array}$ & $\begin{array}{c}\text { Available product is proposed by management of } \\
\text { - interior characteristic (layouts, etc.) }\end{array}$ \\
- performance characteristics incl. price & $\begin{array}{c}\text { And distribution of the product is also done by } \\
\text { sales department or by the company management. }\end{array}$ \\
\hline
\end{tabular}


Evident differences are caused by the fact that large and small manufacturers differ significantly in terms of markets served, customers, company sizes, company hierarchy and organization, etc. Marketing departments and their responsibilities are equal to the size of the company and to the product complexity. While large aircraft manufacturer's marketing department is focused on complex and wide range of issues related to the aircraft small aircraft manufacturer's office is focused mainly on the promotion [31].

\section{Airbus vs. Boeing - marketing warfare}

This chapter provides insights into what biggest players do to win the customer. It also explains sales and marketing processes by two competing manufacturers on a case study. The purpose of the study is to illustrate aircraft sales campaigns of two biggest players on the market and it has no link to any ongoing campaign of any manufacturer.

We have chosen South African Airways for this case study. The airline operates most of its aircraft in hot climate and on airports with higher altitudes. Company runs traditional full-service business model. These facts provide wide range of possibilities for argumentation in sales and marketing process; starting with multiple class cabin layouts going thru performance analysis which has to prove sufficient aircraft performance for hot and high airfield operations and many others such as economics, maintenance, reliability, etc.

\subsection{Desired route and aircraft}

The airline is willing to start a new service from Johannesburg in South Africa to Peking in China. It is looking for an airliner with capability to take-off and land on high and hot airports because of its base in Johannesburg.

The airline is looking for an aircraft with outstanding performance, economics, reasonable costs and yields.

Requested cabin configuration should accommodate two classes; economy and business class. The airline desires higher passenger and cabin crew comfort onboard aircraft. All the details for seating, lavatory and galley dimensions are defined in "ground rules definition" (internal document of manufacturers).

Company also asked for proposals from both manufacturers; Airbus and Boeing. Considered models are Airbus A340-600 and Boeing B777-300ER. Tables 4 and 5 show possible argumentation of both manufacturers with respect to cabin layout and passenger comfort. Table 6 complements the campaign with aircraft performance analysis.

Table 4 Possible marketing argumentation related to the cabin and comfort

\begin{tabular}{|c|c|}
\hline Airbus A340-600 & Boeing B777-300ER \\
\hline Cabin space \\
\hline $\begin{array}{c}\text { Lighter, brighter and more spacious } \\
\text { All first and business class passengers are } \\
\text { guaranteed to have the optimum seating choice }\end{array}$ & $\begin{array}{c}\text { The most spacious passenger cabin ever } \\
\text { developed (cross-section of 229inches) }\end{array}$ \\
\hline & Wider cabin, wider aisle, more space \\
\hline & $\begin{array}{c}\text { Standard business-class seats are 20 inches (50 } \\
\text { cm) wide - the same width as the A340's first- } \\
\text { class seats }\end{array}$ \\
\hline \multicolumn{2}{|c|}{ Passengers' impression } \\
\hline New interior styling & Award-winning interior \\
\hline
\end{tabular}




\begin{tabular}{|c|c|}
\hline $\begin{array}{c}\text { Smoother contours with softened lines - modern } \\
\text { design }\end{array}$ & $\begin{array}{c}\text { When closed, the stowage units fit neatly into the } \\
\text { streamlined contours of the interior architecture } \\
\text { to allow ample overhead clearance }\end{array}$ \\
\hline $\begin{array}{c}\text { State of the art LED lighting - light for any } \\
\text { occasion }\end{array}$ & LED mood lighting \\
\hline $\begin{array}{c}\text { Newly designed Air Conditioning outlets - less } \\
\text { disturbance by look }\end{array}$ & \\
\hline $\begin{array}{c}\text { Lateral light - illuminated side panels } \\
\text { cabins - outstanding passenger experience }\end{array}$ & \\
\hline $\begin{array}{c}\text { A340 passengers sit farther from the } \\
\text { engines than on an equivalent twin - higher } \\
\text { comfort standard }\end{array}$ & \\
\hline
\end{tabular}

Table 5 Possible marketing argumentation related to the cabin and comfort

\begin{tabular}{|c|c|}
\hline \multicolumn{2}{|c|}{ Other cabin advantages } \\
\hline $\begin{array}{c}\text { Modern digital cabin management system - With } \\
\text { a touch-screen panel, crew operation is quick and } \\
\text { simple, fast turnarounds can be achieved to } \\
\text { maximise aircraft utilisation }\end{array}$ & Wider aisle - faster boarding, de-boarding and \\
turnarounds
\end{tabular}

Table 6 Aircraft performance analysis of A340-600 and B777-300ER on Johannesburg international airport

\begin{tabular}{|c|c|c|c|c|}
\hline Figures & $\begin{array}{c}\text { Airbus } \\
\mathrm{A} 340-600\end{array}$ & $\begin{array}{c}\text { Airbus } \\
\mathrm{A} 340-600\end{array}$ & $\begin{array}{c}\text { Boeing } \\
\text { B777-300ER }\end{array}$ & $\begin{array}{c}\text { Boeing } \\
\text { B7777-300ER }\end{array}$ \\
\hline $\begin{array}{c}\text { Maximum } \\
\text { average } \\
\text { temperature } \\
+26^{\circ} \mathrm{C} \\
(\text { equals to } \\
\left.+15^{\circ} \mathrm{C} \text { at } \mathrm{MSI}\right)\end{array}$ & $\begin{array}{c}+26^{\circ} \mathrm{C} \\
\text { (equals to } \\
\left.+15^{\circ} \mathrm{C} \text { at } \mathrm{MSI}\right)\end{array}$ & $\begin{array}{c}+26^{\circ} \mathrm{C} \\
\text { (equals to } \\
+15^{\circ} \mathrm{C} \text { at MSI) }\end{array}$ \\
\hline $\begin{array}{c}\text { Airport pressure } \\
\text { altitude }\end{array}$ & $\begin{array}{c}1694 \mathrm{~m} \\
(5557 \mathrm{ft})\end{array}$ & $\begin{array}{c}1694 \mathrm{~m} \\
(5557 \mathrm{ft})\end{array}$ & $\begin{array}{c}1694 \mathrm{~m} \\
(5557 \mathrm{ft})\end{array}$ & $\begin{array}{c}1694 \mathrm{~m} \\
(5557 \mathrm{ft})\end{array}$ \\
\hline MTOW & 380 tonnes $+15^{\circ} \mathrm{C}$ at MSI) & 368 tonnes & 351,53 tonnes & 322 tonnes \\
\hline $\begin{array}{c}\text { Maximum } \\
\text { payload }\end{array}$ & 55,6 tonnes & 43,6 tonnes & 69,85 tonnes & 40,32 tonnes \\
\hline $\begin{array}{c}\text { Take-off } \\
\text { distance needed }\end{array}$ & N/A & $4400 \mathrm{metres}$ & N/A & $4000 \mathrm{metres}$ \\
\hline
\end{tabular}




\section{Conclusions}

The case study shows different arguments that aircraft manufacturers use to win the customer. Number of supporting arguments need to be provided by different marketing teams:

- Aircraft performance marketing team provides an in-depth analysis of aircraft performance in various stages of its life cycle

- Aircraft maintenance marketing team supports the campaign with information on aircraft maintenance and aircraft airworthiness. Typical arguments of aircraft maintenance marketing team would be the following ones:

- lower maintenance costs than the competitors aircraft maintenance costs

- maintenance commonality with other model - shorter qualification course for maintenance staff - lower education costs - lower labor costs

- shorter distance to the nearest maintenance centre,

- longer checks intervals (more in-service hours)

- longer life of airframe

- Aircraft technical marketing team supports the campaign with arguments referring to aircraft avionics, engines, $\mathrm{CO}_{2}$ emissions, etc. Typical arguments are:

$\circ$ model commonality (similar handling characteristics, Same procedures during flight, approximately $80 \%$ lower transition costs, etc.)

- cockpit instruments upgrade (e.g. CRT monitors to LCD displays)

- advanced navigation aids (RNP,

- state of the art cabin

$\circ \quad$ engine upgrades (usually increasing thrust)

$\circ \quad$ electronic flight bag

○ continual upgrades to meet market requirements and evolution of technology

- aerodynamics improvements

$\circ$ weight reductions

- Aircraft revenue marketing team is to assist when the right economies comes into play. An aircraft is a means of making profit. In order to make profit, the aircraft has to deliver the right economics. The economics of the aircraft concern costs and revenues [27].

Some aircraft sales and marketing warfares last for months or even years. Even if one particular manufacturer succeed in convincing the potential airline that he has a better product, the airline soon has second thoughts. "If their aircraft is better than competitors' one, how come they are not market leaders?"

There's illusion of course, that over the long run, the better product will win. But history, military and marketing, is written by the winners, not the losers.

Winners always have the better product, and they are always available to say so [22].

\section{References}

1. Airbus S.A.S., „www.aibrus.com,“(Online). Available:

http://www.airbus.com/fileadmin/media_gallery/files/tech_data/AC/Airbus-AC_A340500_600_Dec11.pdf.

2. Airbus S.A.S., „www.airbus.com,“(Online). Available:

http://www.airbus.com/aircraftfamilies/passengeraircraft/a340family/a340-

600/specifications/. 
3. Airbus S.A.S., „www.airbus.com,“(Online). Available:

http:/www.airbus.com/aircraftfamilies/passengeraircraft/a340family/a340600/performance/.

4. Airbus S.A.S., „www.airbus.com,“(Online). Available: http://www.airbus.com/aircraftfamilies/passengeraircraft/a340family/a340-600/cabinlayout/.

5. Airbus S.A.S., „www.airbus.com,“(Online). Available:

http://www.airbus.com/aircraftfamilies/cabin-showroom (Online). Available: http://home.anadolu.edu.tr/ mcavcar/common/ISAweb.pdf.

6. Airline glossary, „Airline glossary,“(Online). Available: http://airlineglossary.com/airline-definitions/breakeven-load-factors-blf/.

7. AZ World Airports, ,www.azworldairports.com,“(Online). Available: http://www.azworldairports.com/airports/a2480jnb.cfm.

8. Boeing, „www.boeing.com,“(Online). Available: http://www.boeing.com/commercial/777family/longer_range/index.html.

9. Boeing, ,www.boeing.com,“(Online). Available: http://www.boeing.com/commercial/airports/acaps/777rsec2.pdf.

10. Boeing, ,www.boeing.com,“(Online). Available: http://www.boeing.com/commercial/777family/longer_range/lr_back3.html.

11. CEO, aircraft manufacturer, (Consultation).

12. P. Clark, Buying the big jets: Fleet planning for airlines, (Ashgate Pub Ltd, 2007).

13. Climate temp, „www.cliamtetemp.info,“(Online). Available: http://www.climatetemp.info/south-africa/johannesburg.html.

14. Cohen, H., „www.heidicohen.com,” (Online). Available: http://heidicohen.com/marketing-definition/

15. Eurocontrol, „www.eurocontrol.int,“(Online). Available: http://contentzone.eurocontrol.int/aircraftperformance/details.aspx? cgn=\&cg $=\& I C A O=$ A346\&GroupFilter $=12 \&$ NameFilter $=\& I C A O F i l t e r=A 34$.

16. Eurocontrol, „www.eurocontrol.int,“(Online). Available: http://contentzone.eurocontrol.int/aircraftperformance/details.aspx? cgn=\&cg=\&ICAO= B773\&GroupFilter $=12 \&$ NameFilter $=\& I C A O F i l t e r=B 77$.

17. Google, „www.googlemaps.com,“(Online). Available: $\mathrm{http} / / /$ maps.google.com/maps?q=-26.130243,28.243947\&num=1\&t=m\&z=14.

18. K. Götz, (personal notes from consultations with senior marketing analysts of Airbus, 2011).

19. Investopedia, „www.investopedia.com,“(Online). Available: http://www.investopedia.com/terms/i/industrial-espionage.asp\#axzz1sHZd433W.

20. Investopedia, „www.investopedia.com,“(Online). Available: http://www.investopedia.com/terms/i/industrial-espionage.asp\#ixzz1sHato7TA.

21. P. Mirajkar, senior marketing analyst, (Consultation).

22. A. Ries, Trout J: Marketing warfare; pp. 16-29 (McGraw Hill Professional, 1997)

23. S. guru, „www.seatguru.com,“(Online). Available: www.seatguru.com.

24. South African Airways, „www.flysaa.com,“(Online). Available: http://www.flysaa.com/za/en/flyingSAA/SAAFleet/A340-600_seat_plan.html.

25. South African Airways, „www.flysaa.com,“(Online). http://www.flysaa.com/za/en/Documents/flightschedules/Timetable_22122010.pdf. 
26. South African Airways, „www.flysaa.com,“(Online). http://www.flysaa.com/za/en/Documents/flightschedules/Timetable_22122010.pdf.

27. S. Ústupská, The added value of the cabin in aircraft sales: thesis. Žilina, (University of Žilina, 2011).

28. H. Václavová, small aircraft manufacturer marketing analyst, (Consultation).

29. A.T. Wells, J.G. Wensween, Air Transportation: A management perspective, Fifth edition, Thomson Brooks/Cole, (2004)

30. Wensveen, J: Air transportation; eight edition, Ashgate pp. 281-306 (2015)

31. Wikipedia, ,www.wikipedia.org,“(Online). Available: http://en.wikipedia.org/wiki/South_African_Airways. 